I I UC STUDI ES

ISSN $1813-7733$

Vol. - 3, December 2006 (p 7-18)

\title{
Ambivalence: The Divided Self in Sylvia Plath's Poetry
}

\author{
Mohd. Yasin Sharif*
}

\begin{abstract}
Ambivalence, mixed good and bad feelings about particular entity, individual or circumstance, became a ruling passion in Sylvia Plath's life. These ambivalence and breakdown are closely dealt with in her poems. Confessional poets usually reveal their own personal experiences without straining excruciating sentiment. Sylvia Plath, one of the 1960s most influential confessional poets used the same resentment and anguish that developed from her personal grief as the subject of many of her poems. SP is well known among the celebrities for her ambivalence schizophrenic, schizoid and paranoid nature. As an obsessive-compulsive neurotic, ambivalence dominated both her works as well as her life. This ambivalent personality of SP made her and her works obscure and bizarre to the readers. Many of her poems bear the evidence of narcissism, self-hatred, deep attachment and simultaneously deep hatred towards her dear and near ones. The present study is an endeavor to interpret this complex ambivalent personality of SP in light of her poems, her journals and her letters where she clearly confesses all her neurotic obsessed activities directly, honestly and sincerely without any hesitation. The study will also dug out the true logical reasons that lead to the suicide of a blooming star in her make up.
\end{abstract}

Sylvia Plath received complete attention both from her parents and from her grandparents since her childhood. However, lack of proper attention from her parents after the birth of her brother Warren, Plath paves the way towards her mental disorder. "Warren born on April 27, 1935, whom she apparently did not like at first, as she felt cast out suddenly, all attention being riveted on the little one.” (Majumdar 2002:15) It was more intensified by the so-called early death of her father, Otto Plath. The Smith College girl who topped in all fields let it be curriculum, co-curriculum or extra-curriculum disappointed all those surrounded her. "In her school she was brilliantly successful in everything that she attempted. Apart from securing A and 100 in all her exams, she scored excellently at painting, at writing poems, at playing basketball and as girl guide scout, winning prizes effortlessly. (Majumdar 2002:18) "She was in the habit of getting "high pure string of straight A's" (Plath 1977:42) in all subject all through her academic career. Majumdar (2002:19) illuminates "she graduated from Phillips, winning Honourable Mention in National Scholastics Literary Contest, and was the only student in the school history to earn a sixth letter, as well as an Achievement certificate from Carnegie Institute”. Kopp (1977:79) asserts "she was ambitious in many directions and she rarely did anything without striving to excel." This outstanding twinkling star who produced brilliant and outstanding literary works was labeled as schizophrenic by many. The over-ambitious born talented Plath seek refuge even for the meanest thing, like rejection from creative writing class from Harvard in suicide promoting her reputation as the lady in love with death. To understand her personality syndrome a brief analysis of her mental make-up (which arises from her childhood obsession) in light of psychiatry would be much preferable.

Narcissism was very much evident in her character from her very childhood. Her egocentrism is too clear from Plath's own words: "I do not love; I do not love anyone except myself, this is rather a shocking thing to admit. I am capable of affection for those who

* Assistant Professor, Dept. of English Language \& Literature, International Islamic University Chittagong. 


\section{IIUC Studies, Vol. 3}

reflect my own world.” (Plath 1982:34). Her extreme love and hatred for her father is evident from her Journal. The problem with Sylvia Plath was that she lacks self-confident and security. She always felt a kind of insecurity and sought a secured refuge under the protection of a God like person first from her father and after marriage from her husband. Unfortunately, she was deprived of the cherished security in both cases. Thus, a kind of fear and insecurity was deep-rooted in her personality as she felt the lack of love from both her parents since her childhood. Due to such over-dependence on others, Plath did not grow to be strong both physically and psychologically and was unable to face any kind of crisis she encountered in her life individually and independently. But human life is full of incidents which one has to solve individually and independently. This made Sylvia Plath a bit callous and reluctant to live which paves the way to her final suicide. She extremely loved her God like father but at his early death bitter hatred developed in her towards him. From her Journals, it is clear that her feeling for her father was so deep that she was ready to fight with her mother for her father even to protect the incestuous relationship. But his early death dislocates her whole life. After her father's death, Ted Hughes was the kind of person she was looking for, a father like husband. Thus she compares her husband Ted Hughes as "Ted, in so far as he is a male presence, is a substitute of my father." (Plath 1982:280) Plath can be fully understood if the reason for her ambivalence is fully understood. One vital reason of her ambivalence and conflict with her acquaintances is due to the gap of misunderstanding between what she is and what actually is expected of her. She cared little for the people around her and the customs of the society she lived in. As a result, a conflict and tense always worked between her and the social settlement. She wanted to overcome the limitations of a woman and tried to excel in fields not meant for females which lead her to a quite frustrating situation - an ambivalence culminating to extreme pain and self-mutilation. This societal arrangement has been misunderstood by her that society is a bit partial to mankind and a bit vice to woman folk.

According to Freud, "Sylvia Plath was a paranoid who suffer from a fixation in narcissism". (1985:376) Such narcissist patient always looks for a surrogate if by any chance they lose their dear or near one. In case of Plath, she lost her father at a very early age and all the male person whoever she encountered in her life were the surrogate. She badly searches for the qualities of her father in all men she met with. But everyone on this earth is exclusive and failed her expectation which frustrated her throughout her life. And such kind of failure again and again pushed her towards suicide. Her over love for her father, an Electra complex, leads to an over expectation and estimation of her father, failure to which she developed a bitter hatred towards her father. Such extreme lovehatred, an ambivalent quality, having mixed feelings about something or someone is the theme of most of her poems. This dominating personality or obsession made her an obsessive-compulsive neurotic. This ambivalent personality is the sole reason of her death. The result of extreme conditions is mostly alike. It is evident in the case of Sylvia Plath. Sylvia Plath's work and she herself will be intelligible if we dug deep into the reason of her ambivalence. Another vital reason of such ambivalence lies in her obsession for her father which compelled her to commit suicide with a hope of reuniting with her dead father. All her life and her works reflects this destructive all comprising passion of Sylvia Plath. A threadbare discussion of her works and her life as depicted by herself in her Journal and letters will be preferable in understanding this ambivalent nature of Plath.

The poem 'Daddy' clearly depicts Plath's ambivalent mind. Plath's poem “Daddy" reflects that Plath suffers from Electra complex. She herself admitted that the poem "Daddy is spoken by a girl with an Electra complex." (Plath 1982) The poem depicts her 
as a speaker suffering from deep Electra complex which leads to an incestuous relation between the father and the daughter. In the very beginning of the poem the speaker, Plath addresses her father, Otto Plath as

"Marble -heavy, a bag full of God

Ghastly statue with one gray toe.”

(Daddy 52)

The god like father due to his early death deprived the speaker of all kind of love and affection turns into a devil. "Her father, who abandoned her in death, caused her subsequent hatred for all men." (Phillips 1977) Plath's ambivalence is again nakedly exposed through the line where she compares her much-loved father with the Nazis, Vampire, devil etc. The hatred of the speaker intensifies and she wants to relief herself even from the memories of the father by killing both the father and her husband, the surrogate father. But her ambivalent nature is again unwittingly articulated as "she was sick of the shallow society ladies and their empty talks and she hated men too, for are not they, the prototype of her archetypal father?” (Majumdar 2002: 22)

Ambivalence encompasses all Plath's identity i.e. her works, love towards people and friends surrounding her etc. If we analyze her work, those are also guided by ambivalence. As an obsessive-compulsive neurotic, she finds relief only in her selfexpression through writing. Regarding her writing she boasts, "I want to write because I have the urge to excel in one medium of translation and expression of life. I can't be satisfied with the colossal job of merely living, oh no, I must order life in sonnets and sestinas and provide a verbal reflection for my 60 watt lighted head.” (Plath 1982:81) She esteems her writing as her life circulating blood. She assumes that her writing "would be published, give her hope.” (Plath 1982:109) Her compulsive act of writing makes her God like: "Writing makes me a small god; I recreate the flux and smash of the world through the small ordered word patterns I make. I have powerful physical intellectual and emotional forces, which must have outlets, creative, or they turn to destruction and waste." (Plath 1982:131) Creative writing was on the top of her priority list. She was ready to sacrifice everything- family, children, husband, friends, career, etc. for the sake of writing. She felt a compulsive urge for writing without which she would become sick to death. But often she raves that her writings are not meant for publishing, rather it is a source of ordering her scattered and disordered mind and life. Here lies the ambivalence. At times, she even dares to pronounce that she cares little for name and fame, and to be included in the long list of celebrities- due to her ambivalent nature. Still this ambivalent character evaluates writing as the crucial concern of her existence on this earth. Her ambivalent nature is more exposed after she and her husband, the British writer Ted Hughes's unwise decision to give up all academic missions and decides to reside in England doing all kinds of odd jobs. In a letter to her mother home from abroad she writes: "I feel terribly vulnerable and not myself when I am not writing and I know I can never combine writing and teaching." (Plath 1975 :33) To a compulsive neurotic, like Plath, writing is equated to worship. Plath considered writing as "Writing is a religious act; it is ordering a reforming. The writing lasts. The worst thing, worse than all of them, would be to live without writing." (Plath 1982:272)

Plath's life as well as her work both exposes ambivalence. But this ambivalence is much prominent in her poetry. Most of her later poems were full of disappointment towards marriage and married life, pain and domestic life. While writing these poems, she herself was physically fragile and feeble, yet she was working too hard, at least 'a poem a day before breakfast'. (Plath 1982:74) 


\section{IIUC Studies, Vol. 3}

Plath's out look towards other aspects of life is also ambivalent. In the beginning of her marriage, she regards marriage as an essential requirement to be a complete human being. In this connection she records, "So I began to think that when you were married and have children it was like being brainwashed, and afterwards you went about numb as a slave in some private, totalitarian state.”(Plath 1972:78). Marriage and having children to her were a threat to her writing. In maintaining daily routine of married life she projects, "Some pale, hueless flicker of sensitivity is in me. God: must I lose it in cooking scrambled eggs for a man..... hearing about at second hand, feeling any body and letting my powers of perception and subsequent articulation grow fat and lethargic with disuse.” (Plath 1982:33)

In 1950, the scenario of America was much in favour of family life, marriage and children. Plath was in her twenties at that time. The society was creating a persistent pressure on women to concentrate on their prime duty as a housewife and motherhood. Plath found the situation too difficult to cope. She observed it as a curse that "Marriage is the destiny traditionally offered to women by society. It is still true that most women are married, or have been, or plan to be, or suffer from not being. The celibate woman into be explained and defined with reference to marriage, whether she is frustrated, rebellious, or even indifferent in regard to that institution.” (Beauvior 1997: 3) Thus the ambivalent Plath craved for both roles, a mother as well as a wife but in her own fashion quite different from the instructions of the prevailing social settlement. She projects her assumption of her utopia where she will be the proud possessor of a loving husband, children and enjoy the fruit of a successful career as a poet. She "would live a life of conflict, of balancing children, sonnets, love and dirty dishes; and banging, banging an affirmation of life out of pianos and ski and in bed, in bed, in bed.” (Plath 1982:126) Regarding married life Plath boasts "I have everything in life I've ever wanted: a wonderful husband, two adorable children, a lovely home and my writing." (Plath 1975:458)

Plath considers the position of a bride as a seclude nymph in a deserted island ensuring hope and optimism:

"Side of green Adam, I

Smile, cross-legged, Enigmatical."

(Purdah 60)

The above excerpt establishes the bride as a mysterious one as the husband does not even care to think of her existence. The male considers her as a precious gem, "a small jeweled/doll he guards like a heart". This critical out look of the male folk divides Plath personality into two. The loving and caring beloved wife turns treacherous: "I shall unloose from the small jeweled/doll he guards like a heart/ the lioness,/ the shriek in the bath,/ the cloak of holes.” (The Laugh of the Medusa)

Her ambivalent nature towards marriage is more clearly evident in "The Applicant" where she stigmatized marriage as an artificial thing. The speaker in "The Applicant" is nothing but a domestic mass who can "sew, it can cook/ it can talk, talk, talk". She is considered by the husband a mere appendage, a mere marionette. Plate's attitude towards marriage seems to be too puzzling. Marriage, the holiest institution on this earth considered by many religions is denounced by Plath: "She takes his name, She belongs to his religion, his class, his circle; She joins his family, She becomes his "half". She follows wherever his work call him and determines their place of residence; She breaks more or less decisively with her past, become attached to her husband's universe; She gives him her person, virginility and a rigorous fidelity being required.(Beauvoir 1997:3) 
In this connection, an analysis of her ambivalent relationship with Ted Hughes is worth mentioning. She felt so contented by marrying Ted Huge that she holds their marriage as a barometer in weighing other marriages as successful or a failure. The evidence is proved in her letters to her mother concerning her brother Warren's marriage, "If Warren makes her (his wife) happy anywhere near as happy as Ted has make me, she will be the second happiest woman in the world.” (Plath 1975:154) She further refers to her mother regarding their marriage, "I have everything in life, and I have ever wanted a wonderful husband”. (Plath 1975:487) Ted Huge to Plath was a colossus fatherly like secured figure. "Hughes was large and alarmingly powerful, both physically and in psychological presence." (Copp 1977:73) She did not find any one parallel to her father's quality- "a ghastly godly like figure." (Daddy) After meeting Ted Hughes, she felt "Every woman loves a fascist" (Daddy). Plath utters, "my whole being has grown and interwound so completely with Ted's that if anything were to happen to him, I do not see how I could live. I would either go mad, or kill myself.” (Plath 1982:156) Thus, she confesses he is the perfect male counterpart to me. She turned into a "thirty year old cargo boat" (Tulips) that slips things, after her miscarriage at the age of thirty. In the postoperative chamber, she was reluctant to come back to the irrational society full of criticism and prefer death. At those hard moments of her, Ted Hughes was "the sweetest most thoughtful person in the world." (Plath 1975: 215) The same loving Ted Hughes within a short span of seven years turned into a vampire whom she wanted to kill and eliminate from her life forever. Her ambivalence is clearly reflected here. On a visit to Sylvia's residence Aurelia Plath found that things between her daughter and Ted Hughes were not going smooth. Ted seems to be interested in other women which caused Sylvia "great personal humiliation as rejection by him (Ted) meant a kind of devaluation and falsification of the idea she cherished about marriage.” (Rajni 2000:172). Ted Hughes was so possessive in nature that Sylvia felt "dangerous to be so close to Ted." (Rajni P-172). After their divorce, she seems to be "in heaven, now life is such" (Plath 1975:491-92). Mrs. Plath went as far as to "mock him (Ted) for his weakness and called him a traitor".(Roche 1977:84) She even went so far to record in her Journal that "Living apart from Ted is wonderful - I am no longer in his shadow, and it is heaven to be liked for myself alone, knowing what I want.” (Rajni p-172).

Her poem "Wreath for a Bridal” depicts the picture of joyous marriage ceremony Plath forecasts with Ted Hughes:
"Call here with flying colors all watchful birds
To people the twigged aisles; lead Babel tongues
Of animal to choir: "Love what thresh of wings
Wield guard of honour over there!” Starred with words
Let night bless that Luck-rooted mead of cloves
Where, bedded like angles, two burn one in fever.”

(Wreath for a Bridal 80)

In the above lines, SP seems to simply narrate their union as the joyous and ecstatic union of civilized, unmaterialistic and above all selfless creatures full of bliss without any superficiality. Thus, she esteems their marriage to be an ideal one. She was even ready to do anything for the success of her beloved husband-Ted Hughes. Here lies the ambivalence - to be a devoted wife means the sacrifice of a blooming poet lurking with her, which she cannot. Thus her disturb mind echoes "Boys get married, they take a wife. They took marriage for an enlargement, a confirmation of their existence, but not the more right to exist; it is a charge they assume voluntarily. Thus they can inquire 


\section{IIUC Studies, Vol. 3}

concerning advantages and disadvantages; for them it is one mode of living, not a preordained lot”. (Beauvoir 1997:449)

The poem "The Beast" clearly and vulgarly exposes the beastly nature of a husband. The speaker is so disappointed in her marriage that she stigmatizes the husband: "I have married a cupboard of rubbish." In the following few lines he "was a bull man earlier/ King of my dish, my lucky animal" but consequently becomes "mumblepaws", "Fido little soul, the bowel's familiar". It is not difficult for the readers to guess from her autobiographical hint to her disappointment from her husband Ted Hughes Who is a "Dogsbody" in "Who" and a "Dog-head" devours in "Maenad".

Even her close acquaintances were not free from her ambivalent passion. On occasion we find her a selfless friend while on other occasion she is quite rude and selfish: "I feel the desire to be intensely close to my friends, however the closer I get, the sadder I feel to go away and leave them. (Plath 1975:199). From her biographical writing, The Journal we can explore the complete picture of Plath. She seems not to comply with the friends request rather insist on her own side but still feels a kind of compulsion to oblige at the friends' request. She was torn with the ambivalent passion. Lameyer, Plath's friend asserts, "I later, came to feel that Sylvia's narcissism, a fixation caused at the time of her father's death, prevented her from loving anyone else fully.” (Lameyer 1977:41)

Some more analysis of her relationship with some other close line family members will reveal the sheer quality of her ambivalent nature. One such worth mentioning character is her sister-in-law Olwyn Huges. Sylvia seems like praising and renouncing her at the same time: "A beautiful woman, but extravagant and spendthrift and selfish. She owes Ted 50 dollars. (Plath 1975:287-88) The relationship needs much attention to be understood properly. Sylvia seems to renew her attitudes towards close acquaintances or friends from time to time. Thus, Sylvia Plath admits that she "gets along with her (Olwyn) much better now that she has really accepted me as Ted's wife and like her immensely". (Plath 1975:360) According to records, Sylvia felt "being let-out in the actual presence of sisterbrother reunion.” (Butscher 1977:24) The relationship between two rivals sometimes gets worse. On a Christmas in Yorkshire "Sylvia and Olwyn were engaged in such fierce smuggle that Sylvia fled from the house, remained on the moor, until Ted fetched her." (Butscher 1977:24)

Plath was a very ambivalent character to be understood easily. There is hardly any match for her complex nature. As a mother, also her relationship with the children seems ambivalent. Her reflection and attachment towards the children seem too puzzling to understand. At times she seems to be mad for them: "Things seem much calmer and more peaceful with the baby around than without”.(Plath 1975:375) The same mother wants relieve from the punishment of the children: "I really hunger for a study of my own out of hearing of the nursery where I could be alone, with my thoughts for few hours a day." (Plath 1975:392)

The Plath family being a prominent one in the town was expected by many in parties thrown by publishers where all reputed literary giants would show up. But Mrs. Plath was reluctant to attend such parties just because the responsibilities to the children may be neglected even though there were the temptation of meeting celebrities and literary giants like T. S. Eliot. The same affectionate mother projects that she would go mad if she had to wait on a baby all day. There were rumors about Plath of not being too caring and loving towards the children normally done by mothers. In short, Plath's attitudes towards children were always in ups and down- a extreme complex ambivalence. 
The words and images of Plath's poem "Morning Song” reveal her ambivalent feeling towards her newborn baby. At the beginning of the poem, her fondness for the newborn baby declares her deep fascination and intimation but as she proceeds, she feels the baby as a stranger in her life. At the very beginning of the poem, "Love set you going like a fat gold watch", establishes Plath's deep heart felt love towards the newborn baby. This simple line openly exposes that a mother considers her baby as a part of her life to be treasured as people esteem old watches passed down from generation to generation. The same caring and loving mother in the second stanza contrasts her baby metaphorically to a "new statue". I believe unknowingly the poet expressed her ambivalence through these words. A new statue is not meant to be placed at an intimate place like home, but it is preserved in a restricted museum. Thus comparing her loved baby with a new statue the poet seems to create a great distance between their relationships. The third stanza seems to nudely express the baby as a foreigner to the mother:

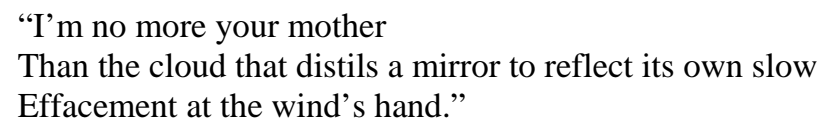

(Morning Song 23)

Though the mother gives birth to the baby as a cloud produces rain which takes the shape of a lake that reflects the cloud, she is in fear of the baby's subsistence. The baby no doubt will resemble the mother, but its uniqueness ultimately will drive it from the mother, as the wind drives the cloud far from the lake.

In "Lesbos" household affairs are "viciousness in the kitchen" including child rearing, an utterly painful experience for Plath. The vicious kitchen is where "potatoes hiss/ it is Hollywood, windowless,/ the fluorescent light winching on and off like terrible migraine". The "viciousness" turns into a murderer, exhausting all the vigor, creativity and prospect and potentiality of woman. This underestimates women and deteriorates her position in the society because "Woman is not called upon to build a better world: her domain is fixed and she has only to keep up the never ending struggle against the evil principles that creep into it; in her war against duty, stains, mud, and dirt she is fighting sin, wrestling with Satan. But it is a sad fate to be required without respite to repel an enemy instead of working towards positive ends, and very often the housekeeper submits to it in a kind of madness that may verge on pervasion, a kind of sadomasochism.” (Beauvoir 1997:471)

Again in 'Tulips" the speaker laments and is reluctant to return home after she had recovered from an appendectomy: "My husband and child smiling out of the family picture/ This smiles catch into my skin, little smiling hooks". (Tulips) Home making taking care of the husband and children seems to be purgation rather than an enjoyment for Plath. Thus, she again and again wanted to escape from reality, responsibility, loved ones etc. The only way out of this bitter situation is death which she ardently prayed for.

In “The Night Dances” Plath's ambivalence is evident where she is too tender towards Nicholas - her second child. The baby is presented as happy, dancing and playing in the crib. But the same loving and caring mother became less spirited towards the end of the poem and compares her baby with snowflakes which bear negative connotations like emptiness, sterility and coldness. 


\section{IIUC Studies, Vol. 3}

"Falling like blessings, like flakes

six-sided white,

On my eyes, my lips, my hair

Touching and melting. Nowhere.”

(The Night Dances 89)

In the "Parliament Hill Fields" Plath's speaker compares the children to "a crocodile" that chase furiously "to swallow" her. A more degraded picture of innocent children is portrayed in "Berck Plage": "These children are often something, with hooks and cries". She even went so far as to call a tender baby a tyrannical and obtruded in "I want, I want”:

"Open-mouthed the baby god

Immense, bold, though, baby-headed

Cried out for the mother's dug."

(Parliament Hill Fields 85)

All these lines established Plath as an ambivalent mother shattering the holy, religious and angelic image of a mother.

Plath's bitter ambivalent towards motherhood is inconsistent. "It is maternity that woman fulfills her physiological destiny; it is her natural "calling", since her whole organic structure is adapted for the perpetuation of the Species". (Beauvoir 1997:501) Plath was dying to be a mother; on the other hand, she is a bit horrified forecasting the up coming responsibilities as a mother. In some places, Plath considers pregnancy as madness. Plath believes that in such cases a woman is deprived of her identity and stoops herself. Her heart-felt raving in this connection is perceivable in "Who" when the speaker says: Let me sit in the flowerpot/ the spider won't notice”.

In "Maenad", the speaker terribly searches her own identity and cries, "Tell me my name". In "The Stone", she turns herself into a fetus:

"I entered the stomach of indifference

Drunk as a fetus

I suck at the paps of darkness".

(The Stone 16)

All the poems depict the ambiguity Plath was undergoing while she was expecting her first child. Almost all the poems prove Plath's annoyance syndrome towards motherhood. Her ambivalence is clearly revealed in most of her optimistic and positive poems. In "Child" a mother desires "colors", "ducks", and "wildflowers - all the elements that are required to live on earth peacefully. The anti-climax occurs in the concluding stanza where the ambivalent mother reluctantly destroys the congenial atmosphere of the society because she is unable to offer the mentioned utopia for her child:

"Not this troublous

Wringing of hands, this dark

Ceiling without a star.”

(Child 90)

Towards the end of her life she tried to find relief by writing poems on babies and tried to find relief in her babies: "For brief moments, perhaps, the mother's love may provide 
partial relief from the otherwise unrelieved world of nightmare". (Plath 1982:86) In poems like "Balloons" and "For a Fatherless Son" Plath's motherly love and affection is deemed by her ambivalence to motherhood. In "For a Fatherless Son" Plath says that the son "will be aware of any absence, presently, / growing beside you like a tree, / a death tree, color gone". We also find dead babies in "Death and Co.". In "Edge" the speaker who is perfected by dead "hail her dead children at her breast."

To Plath nothing is as important as her writing, not even procreativity. The tone is evident in her "Still born"

\begin{abstract}
"These poems do not live: it is a sad diagnosis
They grew their toes and fingers well enough

Their little foreheads bulged with concentration.

If they missed out on walking about like people

It wasn't for any lack of mother-love.”
\end{abstract}

(Still Born 87)

Plath uplifts her poetic creations and optimism that they are Stillborn due to her deep maternal affection despite lot of barriers. In this case "the mother" is equivalent to "a creator". To Plath, the poems are more cherish then her own children which she considers as the off spring of her creative faculty while her children are the product of a natural, biological process. This optimistic view become much acute in "The Munich Mannequins" Plath presents her poetic creation as full of fertility:

"Perfection is terrible, it cannot have children.

Cold as snow breath, it tamps the womb

Where the yew trees blow like hydras,

The tree of life and the tree of life

Unloosing their moons, month after month, to no purpose.”

The Munich Mannequins 74)

The Plath family spends the major period of their life both in America and in England. Thus, Plath has a mixed feeling about both the countries- another ambivalent feature. In this connection, she becomes a bit puzzled in selecting her dwelling place. To her both seem ideal in this way or that way. She esteems "England is so stuffy, cliquey and plain bed." (Plath 1975:293). But, she underestimates it while saying, "The speed and expense of America is just about 50 years ahead of me". She again asserts when she is unable to manage a humble dwelling for her: "London is so enormous in area and very expensive by American standards." (Plath 1975:356) But time and again she was puzzled and baffled to select her dwelling. Sometimes she craves for big cities, the very next moment she craves for the rural: "I do rather miss Boston and don't think I could ever settle for living far from a big city full of museums and theatres". (Plath 1975:353) She defends "Both of us feel wonderful deep-breathing sense of joy at the peaceful seclude, lifeopening for us and delighted that our children will have a wonderful place to live and pay on."(Plath 1975:365) She is further optimistic and says "I have such lovely children and such a lovely home now I only long to share them with loving relatives. I would not leave this place for a million dollars. (Plath 1975:133)

Her assumption and expectation about Devon seems ambivalent equally. Her ambivalent nature towards Devon is much evident in the comparison of it with the Garden of Eden. She considers Devon as "a person, it responds to the slightest touch and looks wonderful immediately.” (Plath 1975:467) But too soon the garden of Eden- 


\section{IIUC Studies, Vol. 3}

Devon lost its appeal to Plath. And the authenticity of such feeling is evident from the assertion, "I shall fight for a London flat, I loved living there, and never wanted to leave and this year of country life has been for me a cultural death. I fight for air and freedom and the culture and the libraries of a city. (Plath 1975:465-68)

Sylvia Plath displayed her ambivalence in choosing her career also. In the very beginning of her career as a teacher at Smith College, she was overwhelmed and too enthusiastic as a teacher. She employed all her energy and talent whole heartedly to become a teacher. In this connection, we find her heart-contented remark to her mother: "I feel a deep need to develop myself respect by teaching, by giving out." (Plath 1975: 63) But soon her enthusiasm evaporates to teaching, like usual. She comments "My ideal of being a teacher, writing a book on the side being an entertaining home maker, cook and write is rapidly evaporating. This life is not the life of a writer.” (Plath 1975:329)

Her ambivalent attitude is reflected in other fields also especially acting. While at college, she was the member of Amateur Dramatic Club which was principally engaged with the production of the students. She was an ardent fellow of the club. But her views on acting again reflect her ambivalence from her expression to her mother, "Unless I get something like the part of Cassandra in 'Troilus and Cresida' I shall become a private person.” (Plath 1975:199) But within a short time, she changed her mind and writes: "The Amateurs Dramatic Club is my extra curriculum life and I enjoy working with these boys and girls. I want to be out on the stage too and create in any way, no matter how small.” (Plath 1975:199)

Plath's attitude towards death also seems ambivalent. Most of her autobiographical poems reveal this truth. In "Lady Lazarus" she boasts that "Dying is an art, like everything else. I do it exceptionally well." These simple but pragmatic lines of her poem prove her fascination towards death. Death is a common practice with her, she again says:

"I have done it again

One year in every ten

I manage it.”

(Lady Lazarus 102)

She further boasts that "And like a cat I have nine times to die." However, the same speaker again unknowingly becomes optimistic to recover and live when she says:

"Soon, soon the flesh

The grave cave ate will be

At home on me

And I a smiling woman."

(Lady Lazarus 102)

Her ambivalence towards life and death is clear from the above lines. She unknowingly craves to live though she calls the doctors who rescued her for her suicide as "Her Doctors, So Herr Enemy.” (Lady Lazarus) The poem Tulips intensifies her ambivalence towards life and death further. SP has a miscarriage and taken to the hospital for treatment. The hospital seems to her as a celestial world, a world of death where she feels eternal bliss. That is why she rejects all her relationship with her husband and children. She wanted to travel to that world again and again but every time she failed in her attempt of suicide. But when the tulips are brought by her 
husband Ted Hughes it projects to her that she is recovering and within a short time she will be taken home. That's why she says about the Tulips "I didn't want any flowers, I only wanted to lie with my hands turned up and be utterly empty" (Tulips). She is too annoyed with the Tulips and says,

"The Tulips should be behind bars like dangerous animals

They are opening like the moth animals of some great African cat”

(Tulips 26)

But the same speaker again is worried at the arrival of the Tulip became "The vivid tulips eat my oxygen" (Tulip). If the Tulip eats her oxygen it helps her to die. "Why does the persona wish to have her own oxygen back when it will keep her alive? Her ambivalence is expressed anyway again.

In retrospect, it can be summed up that SP suffered from a strong mental disorder. The cause of such disorder may be intricate. The one and the foremost are her strong phallic fixation and the early death of her father. And to reunite with him, she prefers to commit suicide. After her father's death, she completely surrendered herself to her husband, Ted Hughes. But he failed to ensure a secured, happy and prosperous life for her due to his illicit love with Assia Wevill. Gradually she lost all her interest in living and again and again tried to seek refuge in death. Thus, ambivalence became her dominating force. She wants to live yet loves to die. All her works exposes this divided self of Plath which proves her to be a mental-psycho. "Each poem is a brief soliloquy in which the poet lays bare her soul. Her inner self suggests emptiness, deprivation and absence of spiritual illumination. There is unity in the poems in the sense that they associate ideas and bring together various moments of a mind contemplating death." (Rajani 2000:195)

SP being a person of outstanding personality felt a kind of leftover by others. She always felt that she was not properly evaluated by others around her according to her merits, potentialities and achievements. She felt a bit undermined by others. Moreover, she tried to supercede human limitations especially those of the feminine and endeavored to accomplish many unusual incidents ending in vain causing extreme fury and soreness. This gradual fury and soreness lead to her ultimate suicide. "Death seemed to be the only way out of a life thwarted emotionally and psychologically." (Rajani 2000:204) She was also a product of a broken family deprived of love and affection since her childhood. This developed a deep insecurity in her which escalated to a masochist instinct in her character. Majumdar asserts, "Thinking of suicide became her way of living and writing”. (2002:26) Another awful reason behind her insanity was that she seemed a bit precocious and immature in her manners and gestures. This precocity and immaturity in her nature was not properly being au fait with by those dwelling around her and they misunderstand her as manipulating them willingly by her. They never commiserate to her. Disdain from others turned her into an obsessive-compulsive neurosis which plagued her whole life. This phobia created a super ego problem in her and she suffered from a double conflict of nervousness and ambivalence. "Her morbid terror, her uncanny death-wish, her unconscious incestuous feeling for her dead father hammering nails in her conscious state drove her to poetry or to madness or to death.” (Majumdar2002:44) Thus, ambivalence dominated her whole personality. Her whole life was in a dilemma between obsession and compulsion which did not let her breath in peace for a single moment. "Her early poetry is a process to sketch out roughly her ordeal of oscillation from life to death, the ambivalent passion to find life-in-death instead of death-in-life.” (Majumdar2002:100) 


\section{IIUC Studies, Vol. 3}

So we can say that her works are the true reflection of her actual personal life throughout. SP posthumously became the symbol of the repressed woman not only through her poetic creations, but also through her suicide. The fact that she put her head in the oven and gassed herself was explained by many as an act of protest against the symbolic death of woman in their cell-kitchen

Notes : The quotations from SP's poems in this article are from:

1. Sylvia. Plath: Collected Poems, chosen by Ted Hughes, London: Faber and Faber, 2002

2. www.americanpoems.com/poets/sylviaplath

\section{References}

1. Beauvior, De Simone (1997), The Second Sex, H.M. Parshley, (ed.), Gallimard: Vintage Books

2. Butscher, Edward (1977), "In search of Sylvia Plath" in Sylvia Plath: The Woman and the Work, Edward Butscher (ed.), New York: Dodd, Mead \& Co.

3. Copp, Jane Baltzell (1977), “Gone, Very Gone Youth”, Edward Butscher (ed.), New York: Dodd, Mead \& Co.

4. Freud, Sigmund (1985), “The Uncanny”, The Pelican Freud Library, James Strachey et.al. (ed.) vol. 14, Harmondsworth: Penguin

5. Kopp, Jane B. (1977), “Gone, very gone, youth” in Sylvia Plath: The Woman and the Work, Edward Butscher (ed.), New York: Dodd Mead \& Co.

6. Lameyer, Gorden (1977), "Sylvia Plath at Smith,” in Sylvia Plath: The Woman and the Work, Edward Butscher (ed.), New York: Dodd, Mead \& Co.

7. Majumdar, Keya (2002), “The Personality”, Sylvia Plath: The Complete Poet, New Delhi: Prestige Books

8. Phillips, Robert (1977), “The Dark Funnel: A reading of Sylvia Plath”, in Sylvia Olath: The Woman and the Work, Edward Butscher (ed.), New York: Dodd, Mead \& Co.

9. Plath, Sylvia (1977), “America, America!”, Johnny Panic and the Bible of Dreams, , London: Faber

10. Plath, Sylvia (1975), Letters Home: Correspondence 1950-63, Aurelia Schober Plath (ed.), London: Faber and Faber Ltd.

11. Plath, Sylvia (1982), The Journals of Sylvia Plath, Ted Hughes and Frances McCullough (eds.), New York: The Dial Press

12. Plath, Sylvia (1972), The Bell Jar, London: Faber and Faber Ltd.

13. Rajani, P. (2000), The Poetry of Sylvia Plath, Hyderabad: Orient Longman Ltd.

14. Roche, Clarissa (1977), "Vignettes From England”, in Sylvia Plath: The Woman and the Work, Edward Butscher (ed.), New York: Dodd Mead \& Co. 